\title{
A REPORT ON A CONSERVATION PLANNING PROCESS FOR A TERRESTRIAL AND MARINE BIODIVERSITY CONSERVATION VISION IN NOVA SCOTIA
}

\author{
KAREN BEAZLEY ${ }^{1 *}$, MARTIN WILLISON ${ }^{1}$, ROBERT LONG ${ }^{2}$ and PAULA MACKAY ${ }^{3}$ \\ ${ }^{1}$ School for Resource and Environmental Studies, Dalhousie University, \\ Halifax, N.S., B3H 3J5, Canada \\ ${ }^{2}$ School of Natural Resources, University of Vermont, \\ Burlington, VT., 05405, USA \\ ${ }^{3}$ The Wildlands Project, \\ P.O. Box 455, Richmond, VT., 05477, USA
}

\begin{abstract}
In May of 1999, a workshop was held to lay the groundwork for a conservation plan to maintain and restore terrestrial and marine biodiversity. The products of the workshop include vision maps and recommendations for biodiversity conservation in Nova Scotia. The wild lands conservation vision identifies existing protected areas, areas suitable for filling gaps in the representation of natural landscape types, and other areas of significant ecological value. Four types of conservation areas are proposed: 1) core areas, to be managed primarily for ecological processes; 2 ) connectivity zones between core areas; 3 ) aquatic/marine zones around islands, headlands, bays, lakes and rivers; and, 4) compatible use zones, which provide a buffer function while allowing for human uses. The wild seas conservation vision includes five conservation categories: 1) marine management units; 2) marine protected areas (MPA's) selected with particular attention to the benthic zones (ocean floor); 3) core "no take" zones in areas of unique or sensitive features, species or assemblages; 4) a special management zone for larval retention; and, 5) a "no-dragger" zone to protect fragile deep sea corals.
\end{abstract}

En mai 1999, on a tenu un atelier visant à préparer le terrain pour un plan de conservation ayant pour but de maintenir et de restaurer la biodiversité terrestre et marine. Les produits de l'atelier comprennent notamment des cartes et des recommandations en ce qui concerne la conservation de la biodiversité en Nouvelle-Écosse. Le projet de conservation des terres sauvages comprend les zones actuellement protégées, les zones qui permettraient de combler les lacunes dans la représentation des types de paysages naturels et d'autres régions importantes sur le plan écologique. On propose d'établir quatre types de zones de conservation : 1) des zones principales, à gérer surtout en fonction des processus écologiques; 2) des zones de connectivité entre les zones principales; 3) des zones aquatiques ou marines autour des îles et des caps, baies, lacs et rivières; 4) des zones d'utilisations compatibles servant de zones tampons et utilisables par les humains. En ce qui concerne la conservation des mers sauvages, on propose cinq catégories de conservation : 1) des unités de gestion marines; 2) des zones de protection marine (ZPM) choisies particulièrement en fonction des zones benthiques (plancher océanique); 3) des zones principales sans prélèvement dans des régions à caractéristiques, espèces ou assemblages d'espèces uniques ou sensibles; 4) une zone de gestion spéciale pour la rétention larvaire; 5) une zone sans dragage pour protéger les coraux fragiles des grands fonds marins.

\section{Introduction}

In May of 1999, approximately 50 individuals participated in the Nova Scotia Wild Lands and Wild Seas Mapping Workshop at Dartmouth, N.S. (Beazley et al. 2000). The goal was to lay the groundwork for a long-range, science-informed wilderness conservation plan to maintain and restore terrestrial, freshwater, and marine biodiversity. The grassroots effort was supported by the Northeastern U.S. regional effort of the Wildlands Project, the Ecology Action Centre (EAC), and the Canadian Parks and Wilderness Society (CPAWS). This intensive two-day planning workshop was intended

* Author to whom correspondence should be addressed.

Biodiversity is the natural variability in individuals and species, and the ecological complexes in which they occur. The range of variability occurs at different levels commonly characterized as genes, species, ecosystems, landscapes and biomes. 
to permit local naturalists, environmentalists and resource managers to quickly and systematically generate an ecological reserve design map or conservation vision as a preliminary guide for long-term conservation planning. It was structured to synthesize the best available ecological information, using conservation biology and landscape ecology principles, into a system of consensus-based maps of conservation lands and seas capable of sustaining the region's ecosystems over the long term. The objectives of this workshop were to:

- $\quad$ produce preliminary maps that, using the best available knowledge, identify lands and marine areas which merit protection to maintain and restore native species and ecosystems;

- provide recommendations to facilitate implementation of a province-wide reserve network;

- $\quad$ increase awareness of the need for a landscape-scale reserve network in Nova Scotia;

- $\quad$ promote cooperation and support regional efforts to develop reserve systems; and,

- inspire conservationists to strive for bold objectives that assure the long-term viability of species and ecosystems.

The workshop was intended to generate preliminary conceptual and ecological information for regional planning, based on existing and accessible map-based ecological data. Other social and economic factors were not considered, although it is acknowledged that these should be incorporated in future refinements and implementation of a conservation plan. The workshop was carried out with limited resources. Approximately $\$ 6000$ (CAN) was provided by the Northeastern U.S. regional effort of the Wildlands Project to 1) hire a part-time coordinator through the EAC to assist with organizational details for the workshop, 2) acquire maps, provide lunch, other refreshments and materials for the participants at the workshop, and 3) produce and circulate a summary report. Second, the time allocated during the workshop for generating maps and recommendations was approximately eight hours, since part of the workshop was used to introduce concepts, objectives, and procedures. Third, systematically-collected and mapped ecological data such as species and ecosystem distribution are limited in extent and accessibility in Nova Scotia. Further, no supplementary data or expert opinions other than those provided at the workshop were incorporated. Thus, while the results generated at this workshop represent a valuable vision for conservation planning, further refinement is required.

\section{Methods}

The workshop was organized by a Steering Committee consisting of representatives from non-government organizations including the Ecology Action Centre, Canadian Parks and Wilderness Society-Nova Scotia chapter (CPAWS-NS), Science and the Management of Protected Areas Association, and the School for Resource and Environmental Studies, Dalhousie University. Approximately 100 people with knowledge of species, ecosystems or conservation planning were invited to participate as individuals or citizens, rather than as representatives of their organizations. These invitations attracted the target number of approximately 50 workshop participants, which allowed a mix of expertise while ensuring adequate access to mapping tables and opportunities for exchanging ideas and reaching consensus. Participants were provided with a package of preparatory information and asked to bring additional 
relevant information. The following resource maps were provided by the workshop organizers:

- 1:250,000 base maps (NSDNR 1999 a);

- 1:250,000 candidate wilderness areas (NSDNR 1999 b);

- $\quad 1: 250,000$ provincial crown land (NSDNR 1999 c);

- 1:250,000 provincial parks (NSDNR $1999 \mathrm{~d}$ );

- 1:250,000 natural landscapes (NSDNR 1999 e);

- 1:250,000 significant ecosites (NSDNR $1999 \mathrm{f}$ );

- 1:125,000 superior heritage resources (NSDNR $1999 \mathrm{~g}$ ); and,

- 1:1,000,000 oceanographic chart (DFO 1984).

At the outset of the workshop, participants were invited to produce initial ecological reserve design maps that could be used as a preliminary framework for long-range conservation planning. Representatives from the Steering Committee, the Northeastern U.S. regional effort of the Wildlands Project, the Wildlands Project, and CPAWS described: 1 ) the process of consensus mapping; 2) definitions of core areas, connectivity zones, and compatible-use areas; and 3) principal components of ecological reserve design, including representation of natural landscape types, species and places of high conservation value (special elements), and habitat for focal species (Soulé 1980, Soulé \& Simberloff 1986, Foreman et al. 1991, Noss 1991, Beazley 1997, Miller et al. 1998/99, Noss et al. 1999, Soulé \& Terborgh 1999, Beazley et al. 2002a).

For the purposes of mapping, the province was divided into three terrestrial regions (eastern, central and western) and one marine region. Participants worked in groups of approximately ten people per map, circulating among the maps throughout the course of the workshop. The conservation vision maps were created by systematically identifying known and suspected areas of high conservation value. The sites were mapped on transparent (mylar) sheets, which could be overlaid on the resource maps that were provided. Site Nomination Forms were completed for each site, noting the: a) ecological significance of the site; b) level of priority (low, medium or high); c) participants' level of certainty or confidence in the conservation value of the site; $d$ ) information sources used; and, e) potential sources of additional information.

Following the mapping exercise, participants collectively defined a series of recommendations to further the biodiversity conservation vision in Nova Scotia. The mapped data and the information from the Site Nomination Forms were subsequently digitized into a Geographic Information System (GIS) by the Northeastern U.S. regional effort of the Wildlands Project, and a summary report (Beazley et al. 2000) was produced and distributed to all participants.

\section{Results}

The maps and recommendations produced through the workshop represent the biodiversity conservation vision for terrestrial and marine components of Nova Scotia. The maps depict an integrated network of core areas, areas of connectivity between them, and compatible-use or buffer zones, which the participants consider to be sufficient to maintain and restore the Province's native species and ecosystems (biodiversity) over the long term (> 100 years). The wild lands and wild seas conservation vision maps for Nova Scotia represent the participants' best preliminary selections of areas that should be protected or restored to a relatively natural condition to maintain biodiversity, including healthy ecosystems (Fig 1 and 2). The maps are 
conceptual and based on existing information, and thus require more-detailed ecological data, field verification and other aspects of refinement. They are, however, a good illustration of key areas of ecological importance and thus high conservation priority, and the extent of wild lands and seas required to sustain species and ecological processes over the long term.

The maps represent the conceptual basis for a long-term (100-year) plan. They are not intended as final conservation plans or reserve designs, but rather as the preliminary, ecological foundation for a more-refined conservation strategy for Nova Scotia. Future planning will require that the concepts represented on these maps be used in conjunction with additional ecological data, as well as social and economic considerations related to, for example, traditional use, agriculture, forestry, fisheries, tourism, recreation, and other aspects of land and sea-based activities, and with input from landowners and other citizens.

\section{Wild Lands: The Terrestrial Vision}

Within Canada, Nova Scotia is ecologically diverse for its size; the Nova Scotia Department of Natural Resources, building upon an ecological land classification scheme developed by the Nova Scotia Museum (Davis \& Browne 1996), identified 80 natural landscape types across the Province (NSDNR 1994). A stated goal of $A$ Proposed Protected Areas Systems Plan for Nova Scotia (NSDNR 1994) is that each of these natural landscape types be represented by a protected Wilderness Area. Thirty-one Wilderness Areas have been designated on Provincial Crown land in Nova Scotia, representing 26 of the natural landscape types. These Wilderness Areas, together with Kejimkujik and Cape Breton Highlands National Parks and other Provincial Parks and Special Places, constitute the backbone of the existing terrestrial protected area system in Nova Scotia, approximately $8 \%$ of the total area of the Province; however, 54 natural landscape types in Nova Scotia are not represented (Beazley 1998).

The wild lands conservation vision map (Fig 1) identifies existing protected areas, as well as areas that could serve to represent each of the 54 natural landscape types that are not yet represented, along with other areas of known ecological value in Nova Scotia. Each of the proposed conservation areas is categorized according to its potential role and management component as one of the following:

- $\quad$ Core Area - relatively large area managed to permit ecological processes to function as naturally as possible;

- Connectivity Zone - linkage or corridor area designed to permit large-scale and long-term ecological processes to continue operating within fragmented ecosystems, such as to facilitate movement of animals (migration, breeding, foraging), plant propagules (seeds, pollen, pollinators), and essential abiotic resources such as water and nutrients;

- $\quad$ Near-shore Aquatic/Marine Protection Zone - area protected primarily for its value to aquatic or marine organisms, or for organisms that require an interface between the aquatic and terrestrial realms; or,

- Compatible-use Zone - area managed for low-intensity human uses and designed to buffer or protect core reserves and critical linkages from the ecological impacts of intensive human activities on adjacent lands.

High-priority core areas include existing protected areas and areas of known ecological significance, in which participants have a high level of confidence in their ecological value. Core areas selected for their potential to represent one of the 54 remaining unrepresented natural landscape types are considered to be of high priority 


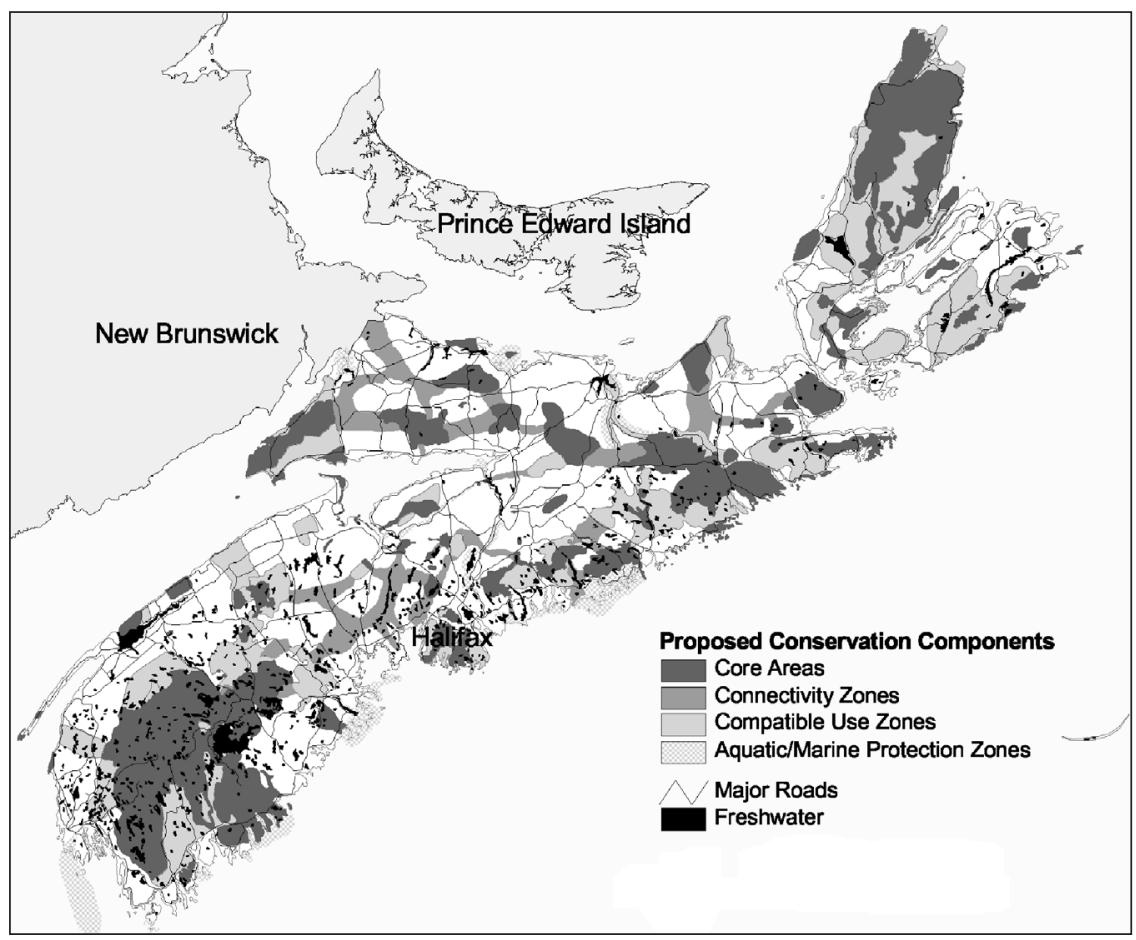

Fig 1 Wild Lands: A Terrestrial Biodiversity Conservation Vision for Nova Scotia. The wild lands vision is a result of the Nova Scotia Wild Lands and Wild Seas Mapping Workshop, held in Dartmouth, NS in May, 1999. Important biodiversity conservation components were identified on a series of 1:250,000-scale maps by approximately 50 local experts over a two-day period. Core areas and connectivity, compatible use and aquatic/marine protection zones were defined on the basis of their ecological importance as representative samples of typical natural landscapes, special elements, and habitat for focal species, along with their spatial functions in creating an interconnected system across the landscape. The total area represented within this biodiversity conservation system is $54 \%$ of the Nova Scotia land base. It is important to note that not all of this area is intended as protected area; rather, human uses compatible with biodiversity objectives that maintain the specific values for which areas have been selected should be defined and encouraged. (Figure prepared by the Northeastern U.S. regional effort of the Wildlands Project.)

because of their conservation value as representative samples. The participants' confidence in their decisions regarding where precisely to locate these areas within each natural landscape is, however, often categorized as low; further research is required to identify precise locations for representative areas. When potential sites for representation exist on both Crown land and private land, sites on Crown land were selected. This method evolved in an ad hoc fashion during the workshop from the participants' assumption that proposing sites for conservation on Crown lands may be a less-controversial approach, particularly in the absence of detailed ecological data. 
This approach requires further consideration, since ecologically important or unique elements occur on both public and private lands, and in some cases private conservation initiatives may be more effective.

Important lands and waters for linking together core areas were identified as connectivity zones. Existing protected areas in Nova Scotia and the core areas proposed in the wild lands vision are not large enough on their own to, for example, maintain viable populations of all native species over the long term (Beazley 1997, 1998, Beazley et al. 2002a, Snaith \& Beazley 2004a). This is also generally the case with protected areas elsewhere in North America and the world (Newmark 1985, 1995, Noss \& Cooperrider 1994). Thus, linkages or areas of connectivity among protected areas are critical for allowing individuals to move between protected areas in order to maintain population size and genetic diversity, to provide source populations for those that suffer local extinctions, and to allow migration and dispersal in response to environmental changes such as climate change (Soulé 1980, Soulé \& Simberloff 1986, Noss \& Harris 1986, Noss 1987, Dobson et al. 1999).

In the wild lands vision, connectivity zones were tentatively identified in areas of natural land cover between core areas, along riparian corridors and along the coast. Connectivity zones are of intermediate conservation priority because of their important long-term function; however, the precise location of these areas requires further refinement to reflect the specific ecological function, such as the habitat requirements of the populations most dependent upon connectivity for long-term persistence (see for example, Beazley et al. 2002a, Snaith et al. 2004).

Near-shore aquatic and marine protection zones were selected to conserve the terrestrial-marine interface, primarily around islands, headlands, and bays. These coastal zones were identified in areas adjacent to core areas, in areas known to be particularly sensitive or significant in their own right, and/or in areas with relatively little human development. In some cases, these zones also serve as coastal-and-near-shore-aquatic connectivity zones among core areas located near the coast, and as compatible-use zones adjacent to core areas.

Compatible-use zones were drawn around many existing and proposed core protected areas so as to buffer these areas from the negative effects of more-intensive human land-use activity on adjacent lands. Compatible-use zones vary in width depending upon the intensity or likelihood of adjacent human activity that might jeopardize the conservation values for which the core area was selected. The range of compatible human uses would vary from area to area, depending upon the specific conservation value or role of the area in question. The compatible-use zones delineated for the wild lands vision are ranked as having intermediate conservation value because of the buffering function for core areas; they may also serve to provide supplemental habitat for species with relatively large area requirements. The participants were uncertain about the most-effective locations and widths of these areas, thus a low-confidence ranking was frequently applied; further research is required to more precisely delineate the boundaries of the compatible-use zones.

It is important to emphasize that the areas of conservation value that were identified and mapped are limited in at least two ways. First, participants based their selections on their own personal knowledge, expertise or experience, and/or on existing and accessible mapped data provided at the workshop. The selection of areas was not based on a Province-wide, systematic inventory of ecological data collected for this purpose and, thus, both the underlying data and the results contain inherent sampling and perceptual biases. The areas that the participants perceive to have high existing conservation value were identified, whereas areas for which ecological information or knowledge is lacking, or those that are currently ecologically compromised but have 
strong restoration potential, may not have been identified. Second, some areas were selected primarily for their spatial function in the conservation vision, such as providing connectivity between core areas or as a potential representative sample of a natural landscape type rather than for other known ecological values. With further ecological data, more effective locations for these connectivity zones and representative areas could be selected that combine the conservation roles and other ecological values.

The combination of all four conservation components (core areas, connectivity zones, compatible use zones and aquatic/marine protection zones) represents the terrestrial conservation vision and includes $54 \%$ of Nova Scotia's land base (Table 1). This $54 \%$ figure is consistent with other studies that suggest that roughly $50 \%$ of the land base (Soulé \& Terborgh 1999, Soulé \& Sanjayan 1998), or between 25\% and 75\% of a region (Noss \& Cooperrider 1994), varying with the particular diversity of species and ecosystems present, is required to prevent further anthropogenic extinctions.

Table 1 Estimated area and percent of Nova Scotia in each conservation component

\begin{tabular}{lcc}
\hline Category Area & $\sim$ Land Area $\left.\mathbf{( k m}^{\mathbf{2}}\right)$ & $\sim \%$ of NS Land \\
\hline Core Areas & 14,795 & 27 \\
Connectivity Zones & 3,592 & 6 \\
Aquatic/Marine Protection Zones & 1,136 & 2 \\
Compatible-use Zones & 10,327 & 19 \\
Total & 29,850 & 54 \\
\hline
\end{tabular}

1. The total area indicated as Aquatic/Marine Protection Zones is $2,496 \mathrm{~km}^{2}$, which includes areas below the high tide mark. Only those areas above the high tide mark $\left(1,136 \mathrm{~km}^{2}\right)$ are included in the calculation of land area and percent of NS land area.

It is important to note that the wild lands vision does not depict precise boundaries for protected areas and is not intended to be a blueprint for land acquisition or preservation. Rather, it is intended to serve as a planning guide to identify areas in the province where short-term, intermediate and long-term conservation initiatives could be directed to maintain biodiversity. Conservation initiatives could include compatible human uses and private stewardship options and incentives, such as conservation easements and tax incentives. The terrestrial biodiversity conservation vision may best be achieved through a system of parks, wilderness areas, wildlife management units, and zones for compatible forms of activities such as traditional hunting, trapping and fishing, commercial forestry, farming, small urban and suburban developments, recreation, and ecotourism. The primary management objective within these areas, however, should be to conserve the biodiversity value for which it was selected. For example, commercial-scale, resource-extractive industry is likely incompatible with the conservation function of a core area, however it may be compatible within certain buffer zones. Similarly, traditional forms of hunting may be compatible with the conservation function of a core area. The challenge for future conservation planning is to translate the wild lands conservation vision into detailed, community-based designs and initiatives that integrate compatible land uses into the landscape in ways that also conserve biodiversity and the function of ecosystems.

\section{Wild Seas: The Marine Vision}

A significant part of the wild seas mapping workshop involved adapting and applying terrestrially-based concepts of systematic biodiversity conservation planning to the ocean environment. Components such as representation of natural regions, 
special elements of high conservation value, and critical habitat areas for focal species were integrated into the vision. For example, as with terrestrial conservation planning, the wild seas conservation vision makes use of biogeographic zoning, but in this case employing the marine theme regions (ecozones) as mapped by the Nova Scotia Museum (Davis \& Browne 1996). An oceanographic chart at 1:1,000,000-scale (DFO 1984), which shows the bathymetry (depth) of the ocean floor surrounding Nova Scotia, was used as a base map.

The wild seas conservation vision map (Fig 2) includes five major components: 1 ) marine management units; 2) marine protected areas; 3) core "no take" areas; and, two special management areas, 4) a larval retention zone, and 5) critical deep water coral habitat. The first component, the marine management units, is identified on the vision map as seven primary units, each having distinctive characteristics based on depth and other enduring oceanographic features as defined by the marine theme regions. These marine management units are primarily concerned with pelagic (water column) characteristics and include the following units:

1. Bay of Fundy (inner and outer);

2. Southwestern Banks and Basins;

3. Central Banks and Basins;

4. Eastern Banks and Basins;

5. Eastern Laurentian Shallows;

6. Bras d'Or Inland Sea; and

7. Deep Abyssal Plain.

Each of these 7 units is proposed as a marine management unit in which the precautionary principle will be applied (for a recent review of the application of the precautionary principle in marine environmental management, see VanderZwaag (2002)). The precautionary principle has generally been defined as a mandate to take precautionary measures when an activity raises threats of harm to human health or the environment, even if cause-and-effect relationships are not fully, scientifically established. The essential objective of management within these zones should be primarily to maintain biodiversity and other elements of ecological health, and secondly to maintain fisheries in ways that do not compromise the primary objective. By including the entire marine realm within these management units, no part of the ocean region is open to human uses that do not sustain the health of the ecosystem.

The remaining four major components of the wild seas conservation vision identify areas that possess specific ecological characteristics or perform critical functions in the marine ecosystem. A series of marine protected areas (MPAs) were identified through a process which focused on characteristics of the ocean floor. MPAs provide a higher level of protection for selected regions of the ocean than is generally the case within the rest of the marine management unit. Keeping in mind the history of failures in marine management, particularly in fisheries, the precautionary principle mandates that MPAs be established as insurance against the failure of other conservation and management measures. MPAs were selected both to represent the diversity of marine theme regions, and to protect unique sites containing fragile benthic (bottom) habitats that support both infauna (fauna within the sediments) and epifauna (fauna attached to the seabed or other organisms such as infauna). MPAs are areas from which activities that may damage sensitive natural communities should be excluded. Restrictions may vary somewhat according to each site, and the precise placement and number of these sites should be revised as better information becomes available. Three of the sites 


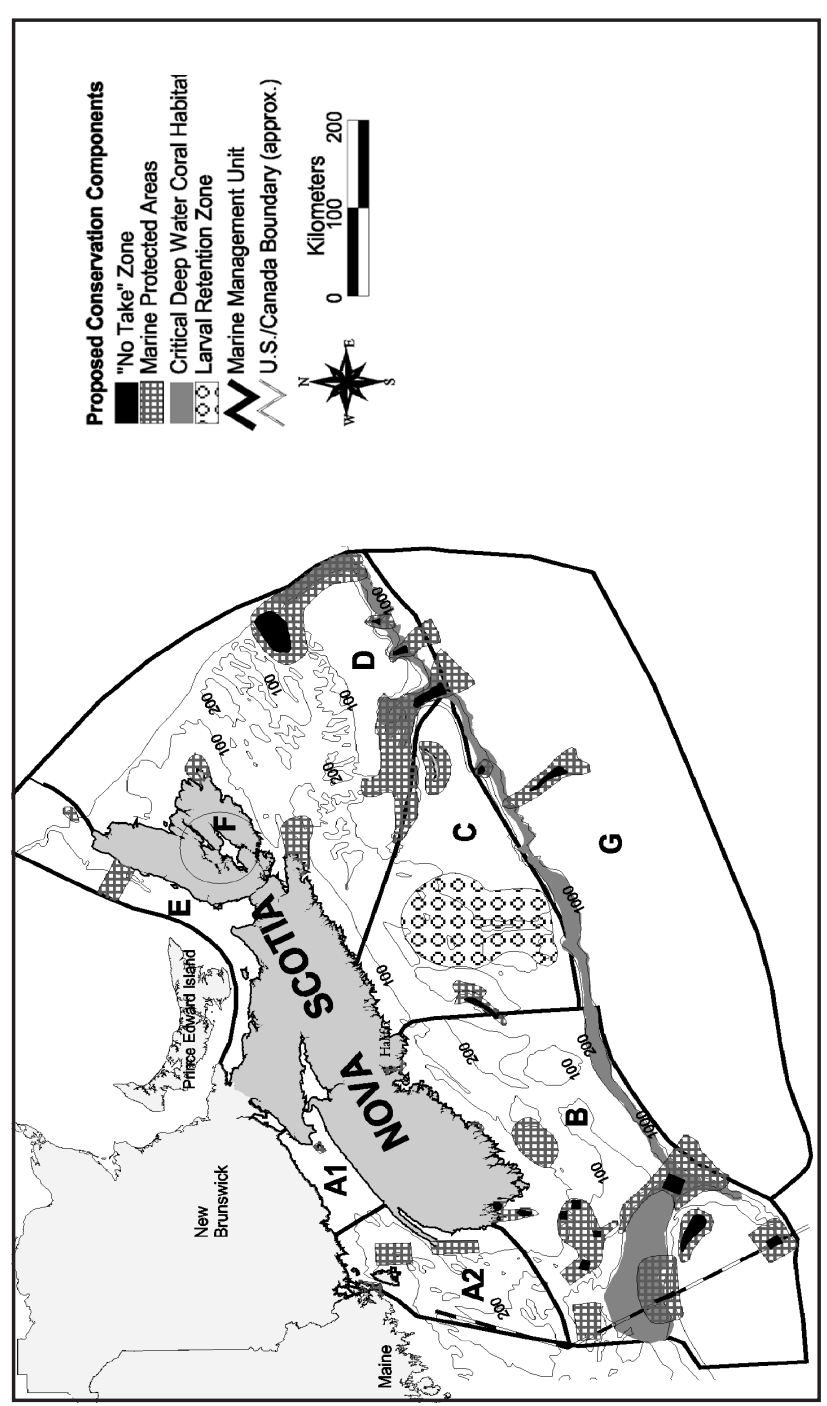

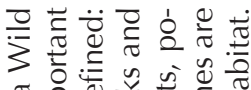

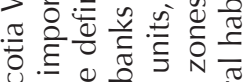

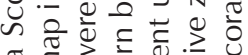
ว

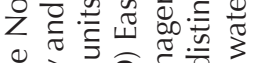

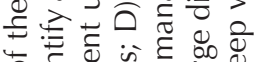
०

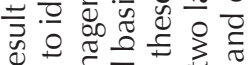
ฮ ๙ิ) 일

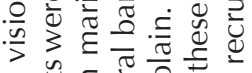
ชิ

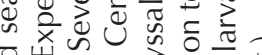

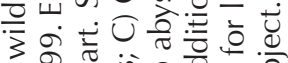

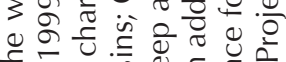
E. U. ه্

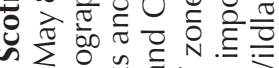

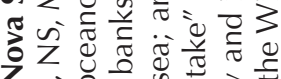

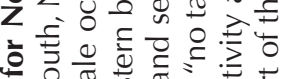

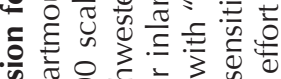
:

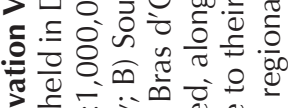

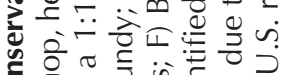

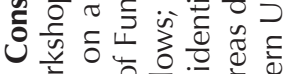

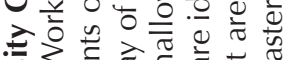
काँ

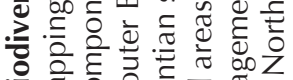

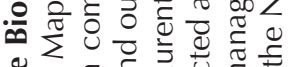

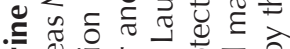

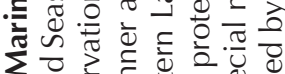

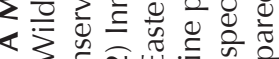

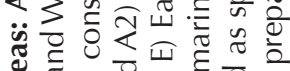

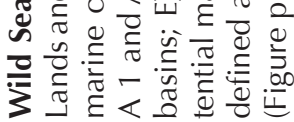
$\underset{10}{201}$ 
(Grand Mannan, Roseway Basin, and the Sable Gully) are intended to protect whales as well as benthic fauna, thus some surface-traffic restrictions should apply within their boundaries. Generally, mobile-fishing gear that is dragged across the ocean bottom should be excluded from these MPAs. Participants agreed that more MPAs are needed than the 27 preliminary MPAs that are indicated in the marine vision; however, more knowledge is required before a comprehensive set can be properly identified.

Within some of these MPAs, participants identified 18 areas that have unique or sensitive features, species or assemblages of species. These areas are proposed as core "no-take" zones. Only about 1\% of the map is designated as "no-take," which is clearly insufficient. These zones have been included as a matter of principle to indicate that there are areas from which all fishing and other exploitative activity should be excluded. The total no-take area should be larger than shown, but because placement of these zones should be based upon reliable survey information, including that obtained through collection of local fishers' knowledge, only a few tentative proposals have been made in the current map.

In addition to these three standard features of the map (management zones, MPAs, and core no-take zones), two large, distinctive zones were also identified. The first is a larval retention area that results from a gyre (a circulatory ocean current) in the middle of the Scotian Shelf. This area is proposed for special management in view of its role in larval settlement and recruitment of juveniles of several species, including many species important to commercial fisheries. The Department of Fisheries and Oceans regards the gyre as a nursery area and protects part of it for this reason. Management within this special zone should place highest priority on the protection of its capacity for recruitment, which can be viewed as a tool for both biodiversity conservation and fisheries management. This is in contrast to MPAs, which have been designated primarily for the purpose of biodiversity conservation, or management units, which have been proposed primarily for fishery management purposes.

The second special zone lies along much of the Scotian Shelf break, the sharp dropoff at the continental margin, at depths of about 250-2000 metres. Corals, sponges, bryozoans and several other large marine invertebrate animals that are attached to the sediment and bedrock along the continental slope and elsewhere stand up from the bottom to various heights. These may be as high as several metres, although they are usually less than a metre in height. These large bottom-dwelling animals provide habitat for numerous other animals in the same way that plants provide habitat for animals on land. Some of the animals that benefit from the structurally-complex habitat provided by these large sedentary invertebrates are free-swimming, like fish and shrimps, while others are attached to the large sedentary invertebrates. For example, the Gorgonian coral Primnoa resedaeformis is often about a metre in height. Individual colonies often have several species of hydrozoans and molluscs attached to them, as well as being surrounded by aggregations of redfish (Sebastes spp.). Because the corals, sponges and bryozoans are large, they are readily damaged by mobile fishing gears, such as groundfish trawls and scallop dredges that are dragged over the bottom behind powerful fishing vessels. As a result, these otherwise robust long-lived animals are rendered fragile.

The complex-branching deep sea corals that are found along the edge of the continental shelf off Nova Scotia create the "forest" that is mapped as a special unit. Protection of this coral forest, which also occurs as isolated patches elsewhere on the Scotian Shelf, is of high priority. Damage to this forest by mobile fishing gear is severe, and thus the region has been mapped as a "no-dragger zone". Exclusion of dragged fishing gear, ocean drilling and mining, and any other activity that disturbs the ocean 
bottom is essential where corals and other structurally-complex features emerge from the bottom. More-precise mapping of these features should therefore be a high priority for future research. Surface traffic and fishing of pelagic species need not be excluded. Once the denser concentrations of corals and areas with dense coral potential have been mapped, more core "no-dragger" areas can be drawn within the coral forest zone.

The wild seas conservation vision map is a starting point for further work, but more input is required before it can be regarded as a "blueprint" for conservation. At the moment, it is simply a blurred picture that needs to be brought into clearer focus if the marine ecosystem is to retain a semblance of health.

\section{Recommendations and other results}

In addition to the mapped wild lands and seas visions, the workshop resulted in the formulation of several recommendations to further the visions and the conservation of biodiversity in Nova Scotia. Key recommendations include: 1) collaboration among non-government organizations, local communities, academic researchers and government; 2) review and refinement of the conservation vision maps by the academic community, conservation organizations, local naturalists and other natural resource experts agencies; and, 3) incorporation by federal and provincial governments of the suggestions arising from the workshop into broader planning and management activities (Table 2).

A number of intangible benefits are also expected to result from the mapping workshop, including increased enthusiasm, coordination, communication and research in protected areas initiatives and other conservation projects in Nova Scotia and

Table 2 Key recommendations for biodiversity conservation arising from the workshop

1. Non-government organizations should work together and with local communities, academic researchers and government agencies to further the work of the mapping workshop, in particular and, more generally, the protected areas system and conservation vision for Nova Scotia.

2. The Nova Scotia wild lands and wild seas conservation vision maps should be reviewed and refined by the academic community, conservation organizations, local naturalists and other natural resource experts. Achievable tasks relating to the refinement of the conservation vision should be identified immediately. For example, additional experts and sources of information recorded on the Site Nomination Forms should be consulted, and the information should be incorporated into the maps and associated database. Information on freshwater aquatic ecosystems, in particular, should be sought and incorporated into the conservation vision.

3. Participants should further the visibility and credibility of the conservation vision and the mapping workshop process/results in appropriate ways. For example, papers should be published in regional scientific and other journals.

4. The Province of Nova Scotia, through the Department of Environment and Labour, should undertake a gap analysis and complete the representative system of protected Wilderness Areas for Nova Scotia.

5. The Province of Nova Scotia should develop and implement, in concert with citizens and non-government organizations, a conservation strategy that includes a comprehensive plan for ecologically-sustainable landscape planning. This plan should form the background for land-use planning and Crown land management in the Province. 
Table 2 cont'd

6. The Province of Nova Scotia and regional and local municipal planning agencies should work cooperatively to incorporate core protected areas, connectivity zones, and compatibleuse zones into their land-use planning documents and strategies. Current protected areas are too small, too few and too isolated to sustain ecological health and biodiversity into the future. These existing areas must be supplemented with additional protected areas, functionally connected to each other, and enlarged and buffered from external effects.

7. The Department of Natural Resources should incorporate ecologically sensitive areas, and core, buffer and connectivity zones into their Integrated Resource Management planning strategy for Provincial Crown lands as Categories 2 and $3^{1}$, allowing only compatible and sensitively managed commercial and recreational uses in these areas.

8. The Department of Fisheries and Oceans should incorporate the suggestions generated in the wild seas conservation vision into their ocean management strategy in general, and into Marine Protected Areas planning in particular. All activities conducted in the marine environment should be conducted using the best available knowledge and the most appropriate technology compatible with a precautionary, conservation-oriented approach.

9. In view of the current poorly regulated management of the marine environment, results from the mapping workshop should be made available for use in any appropriate ways that would foster conservation. A precautionary marine management system encompassing the entire marine region and having a hierarchical structure should be established. This hierarchical structure should take careful account of the protection of marine benthic diversity by employing regionally specific fishing gear restrictions.

10. Terrestrial and marine protected areas and ecosystem management should be considered together and integrated in the coastal zone. A biodiversity conservation vision in Nova Scotia requires consideration of the ecological continuum from land to sea. Cooperative and partnership arrangements towards this end should be pursued.

11. The biodiversity conservation vision for Nova Scotia requires integration into a broader regional context; ecological sustainability and biodiversity cannot be successfully maintained in Nova Scotia in isolation from its surroundings. Wild lands and wild seas mapping workshops should be pursued for the remaining Maritime Provinces to provide a link between Nova Scotia and the remainder of the continent. Such an endeavor could also serve to contribute to a regional wild lands and seas vision for the entire northeastern part of the continent.

1 Category 1: These lands can support a wide range of resource uses (low level of conflict is anticipated among competing users); Category 2: Lands with greater competing values and land uses. Most land uses are permitted, but greater planning or modification is necessary to enhance compatibility (community water supply, wildlife management areas, lands of outstanding scenic, recreational or natural value but not assigned to Category 3); Category 3: Lands specifically allocated to special uses and their availability for other uses is limited or denied (provincial parks, protected areas, ecological reserves, protected beaches) (NSDNR 1997, 4).

beyond. It is likely that the workshop resulted in an increased common understanding of the concepts and methods of biodiversity conservation planning, the creation of a common although preliminary vision, and a renewed sense of cooperation, collaboration and passion. Several projects have been initiated to date, although it is difficult to determine whether these are direct results of the mapping workshop. Examples include the "hotspots" project of the Ecology Action Centre's Wilderness Committee, 
the formation of the Nova Scotia Public Lands Coalition, and further scholarly research into biodiversity conservation planning in Nova Scotia (Beazley et al. 2002 a, b, 2004, Snaith et al. 2004, Snaith and Beazley 2002, 2004 a, b, Smandych 2002). CPAWS-NS and Northeastern U.S. regional effort of the Wildlands Project continue to work towards initiatives that coordinate regional-scaled biodiversity conservation plans, extending beyond provincial and national boundaries in Eastern Canada and the United States.

The methods and format of the workshop proved to be successful. The invitation process resulted in the participation of a near-optimum number and good cross-section of local experts. Timely and consistent completion of the vision was achieved by providing clear goals, objectives, concepts, and mapping instructions to the participants at the beginning of the workshop. Greater circulation of the experts among the three terrestrial-region maps (eastern, central and western) may have provided more-consistent input on a province-wide basis; this could have been accommodated by allocating more time to mapping and less time to introductory presentations, although adequate time to reach a clear understanding of the concepts and methods is also crucial. The creation and circulation of the report, including the vision maps, provided a concrete product for further communication. The GIS-based mapping provided data in a format suitable for future use and refinement as well as for visual communication of the vision. It is critical to the success of the workshop that resources are secured for synthesis, publication and distribution of results.

Existing ecological information for identifying priority areas for biodiversity conservation in Nova Scotia has not been systematically inventoried or mapped, however there are additional data sources that were not included in the mapping exercise. While incorporating additional components may be desirable, it would entail increased preparation and/or mapping time within the workshop itself. Greater synthesis of key ecological data could result in a more-refined and detailed vision, with higher confidence among the participants regarding specific site selection; a follow-up workshop and additional research could serve to facilitate the incorporation of more-detailed and recent data into the vision.

\section{Conclusion}

The Nova Scotia Wild Lands and Wild Seas Mapping workshop is an initial step towards the development of a biodiversity conservation vision for the Province. The resulting maps and recommendations illustrate the appropriate scale, both spatially and temporally, for addressing landscape- and seascape-level ecological goals and the complex challenges that accompany them. The wild lands and wild seas conservation visions, and their interface in the coastal zone, will require diligent review and refinement by a broad spectrum of people and organizations. Additional information and collaborative processes are necessary to develop a more refined conservation vision, and economic, social and political considerations must be incorporated. Nevertheless, it represents an important first iteration of a common vision created by a group of experts with wide-ranging experience and knowledge for biodiversity conservation in the Province and its surrounding seas. 


\section{References}

Beazley K (1997) Ecological considerations for protected area system design: the need for an integrated approach to maintaining biological diversity. Proc NS Inst Sci 41:59-76

Beazley K (1998) A focal-species approach to biodiversity management in Nova Scotia. PhD thesis, Dalhousie University, Halifax

Beazley K, Austin-Smith P Jr, Rader M (2002a) Toward completing a protected areas system for Nova Scotia: terrestrial and marine. In: Bondrup-Nielsen S, Munro N (eds) Managing protected areas in a changing world. Proceedings of the Fourth International Conference on Science and the Management of Protected Areas, 1419 May, 2000, SAMPAA, Canada, p 516-530

Beazley K, Long R, MacKay P (2000) Nova Scotia Wild Lands and Wild Seas Mapping Workshop. The Greater Laurentian Wildlands Project, South Burlington, VT

Beazley K, Snaith T, MacKinnon F, Colville D (2004) Road density and potential impacts on wildlife species such as moose in mainland Nova Scotia. Proc NS Inst Sci 42:339-357

Beazley K, Willison M, King M (2002b) Marine protected areas strategies for Nova Scotia. Wild Earth 12:80-86

Davis D, Browne S (eds) (1996) Natural history of Nova Scotia, Vol 2. Theme regions, rev edn. Nova Scotia Department of Education and Culture, Nimbus Publishing and Nova Scotia Museum, Halifax

DFO (Department of Fisheries and Oceans) (1984) 1:1,000,000 oceanographic/ hydrologic chart. Canadian Hydrologic Services, Fisheries and Oceans Canada, Ottawa

Dobson A, Ralls K, Foster M, Soulé ME and 11 others (1999) Corridors: reconnecting fragmented landscapes. In: Soulé ME, Terborgh J (eds) Continental conservation: scientific foundations of regional reserve networks. Island Press, Washington, DC, p 129-170

Foreman D, Davis J, Johns D, Noss R, Soulé M (1991) The Wildlands Project. Wild Earth 1: 3-4

Miller B, Reading R, Strittholt J, Carroll C and 7 others (1998-1999) Using focal species in the design of nature reserve networks. Wild Earth 9:81-92

Newmark WD (1985) Legal and biotic boundaries of western North American National Parks: a problem of congruence. Biol Conserv 33:197-208

Newmark WD (1995) Extinction of mammal populations in western North American national parks. Conserv Biol 9:512-526

Noss RF (1987) Corridors in real landscapes: a reply to Simberloff and Cox. Conserv Biol 1:159-64

Noss RF (1991) The Wildlands Project: land conservation strategy. Wild Earth 1:10-25

Noss RF, Cooperrider AY (1994) Saving nature's legacy: Protecting and restoring biodiversity. Island Press, Washington, DC

Noss RF, Harris LD (1986) Nodes, networks, and MUMs: preserving diversity at all scales. Environ Manag 10:299-309

Noss RF, Dinerstein E, Gilbert B, Gilpin M, Miller BJ, Terborgh J, Trombulak S (1999) Core areas: where nature reigns. In: Soulé ME, Terborgh J (eds) Continental conservation: scientific foundations of regional reserve networks. Island Press, Washington, DC, p 99-128

NSDNR (Nova Scotia Department of Natural Resources) (1994) A proposed systems plan for parks and protected areas in Nova Scotia. Parks and Recreation Division, Department of Supply and Services, Publishing Division, Halifax 
NSDNR (1997) Managing natural resources on crown lands. IRM Report 97-1, Integrated Resource Management, Central Region. Nova Scotia Department of Natural Resources, Halifax

NSDNR (1999) a) Base maps; b) Map of candidate wilderness areas; c) Map of provincial crown land; d) Map of provincial parks; e) Map of natural landscapes; f) Map of significant ecosites; g) Map of superior heritage resources. Nova Scotia Department of Natural Resources, Halifax. Unpublished

Smandych L (2002) Selecting core areas for biodiversity conservation in Nova Scotia. MES thesis, Dalhousie University, Halifax

Snaith T, Beazley K (2002) Moose (Alces alces americana Peterson) as a focal species for reserve design in Nova Scotia, Canada. Nat Areas J 22:235-240

Snaith T, Beazley K (2004 a) Population viability: theory and application to moose in mainland Nova Scotia. N Am Moose Conf Worksh 38: (in press)

Snaith T, Beazley K (2004 b) The distribution, status and habitat associations of moose in mainland Nova Scotia. Proc NS Inst Sci 42:263-317

Snaith T, Beazley K, MacKinnon F, Duinker P (2004) Habitat suitability analysis for moose in Nova Scotia. N Am Moose Conf Worksh 38: (in press)

Soulé ME (1980) Thresholds for survival: maintaining fitness and evolutionary potential. In: Soulé ME, Wilcox BA (eds) Conservation biology: an evolutionary-ecological perspective. Sinauer Associates, Sunderland, MA, p 151-169

Soulé ME, Sanjayan M (1998) Conservation targets: Do they help? Science (Wash DC) 279:2060-2061

Soulé ME, Simberloff D (1986) What do genetics and ecology tell us about the design of nature reserves? Biol Conserv 35:19-40

Soulé ME, Terborgh J (eds) (1999) Continental conservation: scientific foundations of regional reserve networks. Island Press, Washington, DC

VanderZwaag D (2002) The precautionary principle and marine environmental protection: slippery shores, rough seas, and rising normative tides. Ocean Develop Intern Law 33:165-188 